\title{
STUDI TENTANG KETERSEDIAAN FASILITAS WORKSHOP OTOMOTIF SMKN 8 BANDUNG BERDASARKAN STANDARSARANA PRASARANA PENDIDIKAN NASIONAL UNTUK MEMENUHI STANDAR UJI KOMPETENSI
}

\author{
Tanggu M. Habeahan", Inu H. Kusumah ${ }^{2}$, Uli Karo-Karo ${ }^{3}$ \\ Departemen Pendidikan Teknik Mesin \\ Universitas Pendidikan Indonesia \\ Jl. Dr. Setiabudhi No. 207 Bandung 40154 \\ tanggu_habeahan@yahoo.com
}

\begin{abstract}
ABSTRAK
Tujuan dari penelitian ini adalah untuk memperoleh gambaran tentang sarana prasarana di workshop SMK 8 bandung terhadap pemenuhan standar uji kompetensi teknik otomotif berdasarkan instrumen verifikasi SMK penyelenggara ujian praktik kejuruan. Penelitian dilakukan karena masih banyaknya SMK yang belum memenuhi standar sarana prasarana berdasarkan standar pendidikan nasional. Metode yang digunakan dalam penelitian ini adalah metode deskriptif dengan pendekatan kuantitatif. Teknik pengumpulan datanya menggunakan instrumen data observasi dan dokumentasi. Instrumen dilakukan setelah mendapatkan data dari hasil observasi dan dokumentasi. Hasil penelitian menunjukkan persentase pemenuhan standar sarana prasarana workshop SMK Negeri 8 Bandung berdasarkan standar sarana prasarana pendidikan nasional dalam memenuhi standar uji kompetensi.
\end{abstract}

Kata kunci: ketersediaan sarana prasarana, standar pendidikan nasional, kompetensi.

\section{PENDAHULUAN}

Pendidikan berkualitas diharapkan dapat menghasilkan sumber daya manusia (SDM) yang mampu menjadi ahli serta dapat bekerja dalam bidang tertentu. Salah satu usaha untuk menghasilkan SDM yang diharapkan dapat bekerja dalam bidang tertentu adalah pendidikan kejuruan. Pendidikan kejuruan adalah pendidikan pada jenjang menengah yang mengutamakan pengembangan kemampuan siswa untuk melaksanakan jenis pekerjaan tertentu. Peran serta fungsi pendidikan kejuruan adalah menyiapkan peserta didik mampu meningkatkan kualitas hidup, mampu mengembangkan dirinya, dan memiliki keahlian juga keberanian membuka peluang kerja untuk meningkatkan penghasilan (Kemendiknas, 2008).

Peningkatan prestasi siswa khususnya lulusan SMK sangat diharapkan, salah satu faktor peningkatan prestasi siswa adalah lengkapnya sarana dan prasarana yang dimiliki oleh sekolah itu sendiri, dijelaskan dalam Peraturan Menteri Pendidikan Nasional Republik Indonesia No 40 Tahun 2008 tentang Standar Sarana Prasarana untuk Sekolah Menengah Kejuruan (SMK) dan Madrasah Aliyah Kejuruan (MAK) pasal 4 dijelaskan bahwa

\footnotetext{
${ }^{1}$ Mahasiswa Departemen Pendidikan Teknik Mesin FPTK UPI

${ }^{2}$ Dosen Departemen Pendidikan Teknik Mesin FPTK UPI

${ }^{3}$ Dosen Departemen Pendidikan Teknik Mesin FPTK UPI
} 
penyelenggara Sekolah Menengah Kejuruan/Madrasah Aliyah Kejuruan (SMK/MAK) wajib menerapkan standar sarana dan prasarana Sekolah Menengah Kejuruan/Madrasah Aliyah Kejuruan (SMK/MAK) sebagaimana diatur dalam Peraturan Menteri ini, selambatlambatnya 5 (lima) tahun setelah Peraturan Menteri ini diterapkan. Mengingat pentingnya kelengkapan sarana prasarana di workshop otomotif, perlu adanya identifikasi kelengkapan sarana prasarana workshop otomotif khususnya sarana prasarana di workshop otomotif di SMKN 8 Bandung.

Tujuan yang ingin dicapai pada penelitian ini yaitu untuk memperoleh gambaran tentang kelengkapan standar sarana dan prasarana di workshop otomotif SMKN 8 Bandung dan memperoleh gambaran tentang sarana prasarana di Workshop otomotif SMK Negeri 8 Bandung terhadap pemenuhan standar uji kompetensi Teknik Mekanik Otomotif SMK berdasarkan instrumen verifikasi SMK Penyelenggara Ujian Praktik Kejuruan.

Workshop/bengkel dapat diartikan sebagai tempat pelaksanaan kegiatan belajar mengajar keterampilan. Bengkel bukan hanya berarti bengkel tempat praktik peserta didik, tetapi juga tempat para instruktur mengajarkan keterampilan kepada para peserta didik agar mereka mencapai tujuan belajar secara efektif dan efisien. Sarana pendidikan adalah prasarana merupakan penunjang proses pendidikan di sekolah, seperti sarana yang telah dijelaskan sebelumnya. Prasarana pendidikan di sekolah dapat diklasifikasikan menjadi dua macam, yaitu prasarana langsung dan prasarana tidak langsung. Sarana pendidikan yang habis pakai merupakan bahan atau alat yang apabila digunakan dapat habis dalam waktu yang relatif singkat (Barnawi \& Arifin, 2012). Misalnya, kapur tulis, tinta printer, kertas tulis, dan bahan-bahan kimia untuk praktik. Ada pula sarana pendidikan yang berubah bentuk, misalnya kayu, besi, dan kertas karton yang sering digunakan oleh guru dalam mengajar. Selain itu, sarana pendidikan tahan lama adalah bahan atau alat yang dapat digunakan secara terus menerus atau berkali-kali dalam waktu yang relatif lama. Sarana pendidikan yang bergerak merupakan sarana pendidikan yang dapat digerakkan atau dipindah-tempatkan sesuai dengan kebutuhan para pemakainya. Contohnya meja dan kursi, almari arsip, dan alat-alat praktik. Kemudian, untuk sarana pendidikan yang tidak bergerak adalah sarana pendidikan yang tidak dapat dipindahkan atau sangat sulit jika dipindahkan.

Hubungannya dengan proses pembelajaran tersebut, sarana pendidikan dapat dibedakan menjadi tiga, yaitu alat pelajaran, alat peraga, dan media pengajaran. Alat pelajaran adalah alat yang dapat digunakan secara langsung dalam proses pembelajaran, misalnya buku, alat peraga, alat tulis, dan alat praktik. Alat peraga merupakan alat bantu 
pendidikan yang dapat berupa perbuatan-perbuatan atau benda-benda yang dapat mengkonkretkan materi pembelajaran. Materi pembelajaran yang tadinya abstrak dapat dikonkretkan melalui alat peraga sehingga peserta didik lebih mudah dalam menerima pelajaran (Arbor, 1992). BSNP atau Badan Standar Nasional Pendidikan adalah badan mandiri dan independen yang bertugas mengembangkan, memantau pelaksanaan, dan mengevaluasi standar nasional pendidikan. BSNP 1289-P2-13/14 yaitu Standar yang dikeluarkan oleh BSNP tentang sebuah Instrumen Verifikasi SMK Penyelenggara Ujian Praktek Kejuruan untuk Jurusan Teknologi Kendaraan Ringan. Instrument ini di dalamnya terdapat beberapa standar yaitu: (1) Standar persyaratan peralatan utama; (2) Standar persyaratan peralatan pendukung; (3) Standar persyaratan tempat/ruang; dan (4) Persyaratan penguji. Mengenai standar sarana prasarana sesungguhnya sudah tercantum di dalam Permendiknas No. 40 tahun 2008, tetapi kurang terperinci mengenai spesifikasi perangkat utama yang terperinci, oleh karena itu BSNP 1289-P2-13/14 ini melengkapi semua standar sarana prasarana. Kompetensi merupakan evalusi hasil belajar siswa selama belajar dan bisa dijadikan sebagai alat ukur keberhasilan siswa dan guru dalam melaksanakan pembelajaran di sebuah sekolah. Awalnya kegiatan uji kompetensi ini akan dilaksanakan sebelum Ujian Nasional. Uji kompetensi adalah suatu sarana untuk menguji kemampuan siswa apakah siswa ini kompeten atau tidak kompeten di dalam mata diklat yang telah diberikan. Pembelajaran berbasis kompetensi adalah pembelajaran yang dilakukan dengan orientasi pencapaian peserta didik, sehingga muara akhir hasil pembelajaran adalah meningkatnya kompetensi peserta didik yang dapat diukur dalam pola sikap, pengetahuan, dan keterampilannya. Tempat uji kompetensi adalah tempat yang memenuhi persyaratan sebagai tempat untuk melaksanakan uji kompetensi sesuai dengan materi dan metoda uji kompetensi yang akan dilaksanakan.

Penyelenggaraan ujian praktik melalui beberapa tahanpan yaitu: tempat penyelenggaran ujian praktik kejuruan harus memenuhi syarat kelayakan, untuk itu perlu dilakukan verifikasi kelayakan satuan pendidikan atau tempat penyelenggaraan ujian Praktik Kejuruan; verifikasi kelayakan satuan pendidikan/tempat penyelenggaraan ujian Praktik Kejuruan dilakukan oleh Penyelenggara Tingkat Provinsi dengan menggunakan instrumen verifikasi yang telah disiapkan oleh Penyelenggara Tingkat Pusat; penyelenggara Tingkat Provinsi membentuk Tim Verifikasi dengan melibatkan unsur dunia usaha/dunia industri atau institusi mitra yang relevan; apabila diperlukan Penyelenggara Tingkat Provinsi dapat mendelegasikan pelaksanaan verifikasi tempat ujian Praktik Kejuruan kepada Dinas Pendidikan Kabupaten/Kota; dan penetapan kelayakan 
satuan pendidikan/tempat penyelenggaraan ujian Praktik Kejuruan serta SMK yang menggabung dilakukan oleh Penyelenggara Tingkat Provinsi atau Kabupaten/Kota (apabila didelegasikan) berdasarkan rekomendasi Tim Verifikasi.

Penguji terdiri atas gabungan penguji internal dan eksternal; penguji Praktik Kejuruan direkomendasikan oleh Penyelenggara Tingkat Satuan Pendidikan dan ditetapkan oleh Penyelenggara Tingkat Kabupaten/kota; penguji Internal berasal dari guru produktif yang relevan dengan pengalaman mengajar minimal 5 tahun dan memiliki pengalaman kerja/magang di dunia usaha/industry; penguji eksternal berasal dari dunia usaha/industri/ asosiasi profesi/institusi mitra yang memiliki latar belakang pendidikan dan/atau pengalaman kerja yang relevan dengan Kompetensi Keahlian yang akan diujikan; dan penguji memiliki sertifikat kompetensi/surat keterangan kompetensi dari dunia usaha/industri atau institusi mitra.

\section{METODE PENELITIAN}

Penelitian ini menggunakan metode deskriptif dengan pendekatan kuantitatif. Metode digunakan untuk mendapatkan data yang valid dengan tujuan dapat ditemukan, dikembangkan, dan dibuktikan, suatu pengetahuan tertentu sehingga pada gilirannya dapat digunakan untuk memahami, memecahkan, dan mengantisipasi masalah dalam bidang pendidikan. Proses yang dilakukan dalam penelitian ini berdasarkan rencana awal sampai akhir yang dibuat sesuai dengan kebutuhan.

\section{HASIL PENELITIAN}

Hasil penelitian telah diperoleh yaitu standar persyaratan peralatan utama, persyaratan tampat/ruang, penguji internal, dan penguji eksternal semuanya sudah sanagat layak untuk menyelenggarakan ujian kompetensi. Ketercapaian sarana prasarana (Gambar 1) yang disesuaikan terhadap Peraturan Menteri Pendidikan Nasional Nomor 40 Tahun 2008 Tentang Standar Sarana dan Prasarana Sekolah Menengah Kejuruan/Madrasah Aliyah Kejuruan dan Instrumen Verifikasi SMK Penyelenggara Ujian Praktik Kejuruan dari BSNP. 


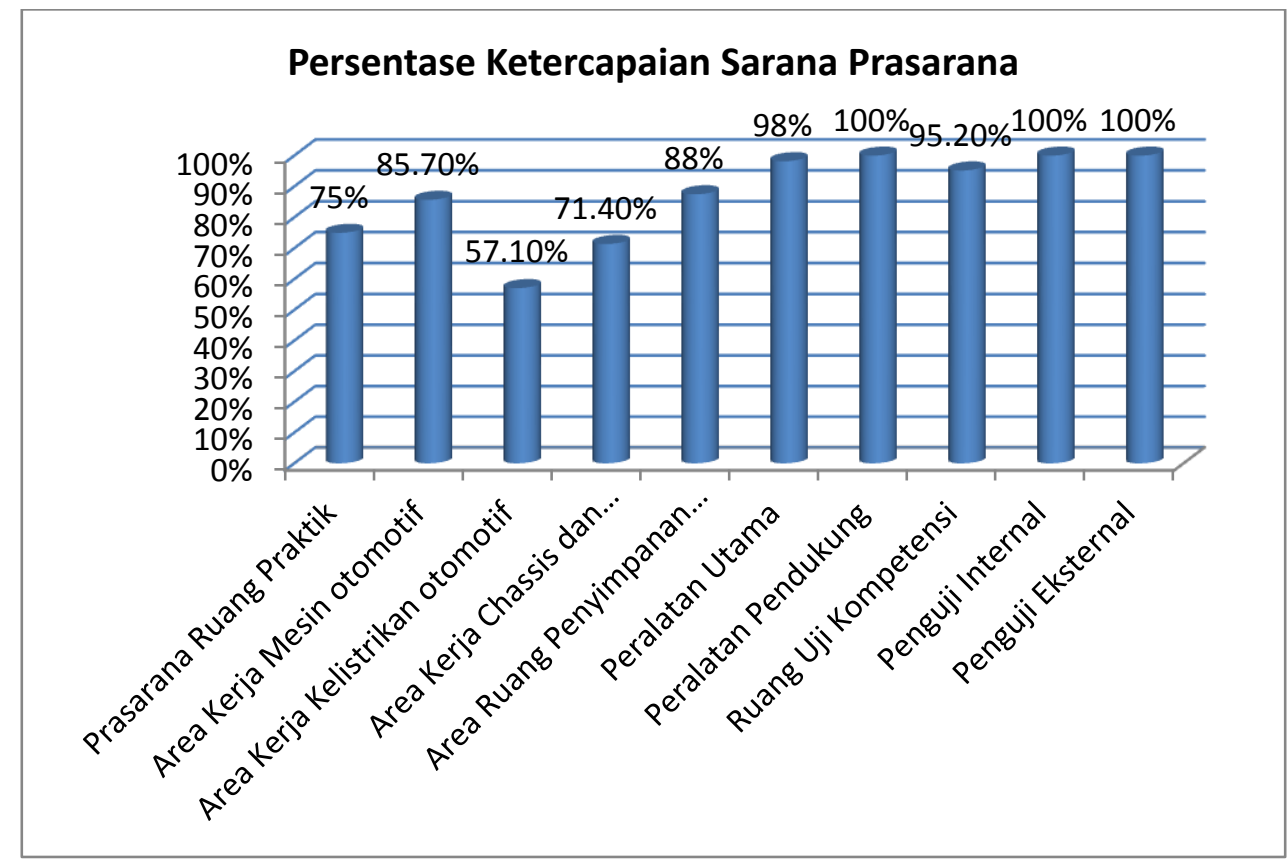

Gambar 1. Diagram ketercapaian sarana prasarana ruang praktik di workshop otomotif

\section{PEMBAHASAN}

Pada bagian ini akan dibahas tentang hasil dari pengambilan data di lapangan yang disesuaikan dengan standar yang ada dan akan dipaparkan sejelas mungkin untuk mengetahui pemaparan data dari hasil observasi dan dokumentasi. Adapun hal-hal yang akan dibahas diantaranya prasarana workshop otomotif, sarana di area kerja engine otomotif, sarana di area kerja kelistrikan otomotif, sarana di area kerja chassis dan pemindah tenaga, sarana di area instruktur dan tempat penyimpanan, persyaratan alat utama uji kompetensi, persyaratan alat pendukung uji kompetensi, persyaratan penguji internal uji kompetensi, persyaratan penguji eksternal, dan persyaratan tempat/ruang uji kompetensi.

Kondisi sarana di workshop Teknik Mekanik Otomotif SMK Negeri 8 Bandung yang ada sekarang sudah memenuhi Standar Nasional pendidikan. Pertanyaan tersebut akan dijawab sesuai tujuan untuk memperoleh gambaran tentang sarana di workshop. Pencapaian standar sarana pada area kerja mesin otomotif di workshop otomotif mencapai $85,7 \%$. Artinya tingkat ketercapaian untuk standar sarana di area kerja mesin otomotif workshop otomotif dinyatakan sangat layak/sangat lengkap.

Lingkungan fisik tempat belajar mempunyai pengaruh penting terhadap hasil pembelajaran. Lingkungan fisik yang menguntungkan dan memenuhi syarat minimal 
mendukung meningkatnya intensitas proses pembelajaran dan mempunyai pengaruh positif terhadap pencapaian tujuan pengajaran.

Pencapaian standar sarana pada area kerja kelistrikan otomotif di workshop otomotif mencapai $57,1 \%$. Artinya tingkat ketercapaian untuk standar sarana di area kerja kelistrikan otomotif workshop otomotif dinyatakan kurang layak/kurang. Pencapaian standar sarana pada area kerja chassis dan pemindah tenaga di Workshop otomotif mencapai71,4\%. Artinya tingkat ketercapaian untuk standar sarana di area kerja chassis dan pemindah tenaga otomotif workshop otomotif dinyatakan layak/lengkap.

Pencapaian standar sarana pada ruang penyimpanan dan instruktur di workshop otomotif mencapai $87,5 \%$. Artinya tingkat ketercapaian untuk standar sarana di ruang penyimpanan dan instruktur workshop otomotif dinyatakan sangat layak/sangat lengkap. Sarana pada area kerja mesin otomotif, sarana pada area kerja kelistrikan otomotif, sarana pada area kerja chassis dan pemindah tenaga. Sarana pada ruang penyimpanan dan instruktur dinyatakan sangat layak/sangat lengkap dan sangat memadai. Sehingga dapat dilakukan proses belajar mengajar dan mendukung meningkatnya proses belajar mengajar seperti yang dikemukakan oleh pakar pendidikan di atas.

Pencapaian standar prasarana ruang praktik di workshop otomotif mencapai $75 \%$. Artinya tingkat ketercapaian untuk standar prasarana dinyatakan layak/lengkap yang disesuaikan terhadap Peraturan Menteri Pendidikan Nasional N. 40/2008 Tentang Standar Sarana dan Prasarana Sekolah Menengah Kejuruan/Madrasah Aliyah Kejuruan.

Sarana dan prasarana yang terdapat di workshop Teknik Mekanik Otomotif SMK Negeri 8 Bandung bisa memenuhi standar uji kompetensi. Pertanyaan tersebut akan dijawab sesuai tujuan untuk memperoleh gambaran tentang standardisasi uji kompetensi Teknik Mekanik Otomotif SMK berdasarkan BSNP. Pencapaian standar peralatan utama uji kompetensi di workshop otomotif mencapai 98,2\%. Artinya untuk ketercapaian standar peralatan utama uji kompetensi di workshop otomotif dinyatakan sangat layak dengan mendapat skor 2,94 yang disesuaikan terhadap instrumen verifikasi SMK Penyelenggara Ujian Praktik Kejuruan dari BSNP.

Pencapaian standar peralatan pendukung uji kompetensi di workshop otomotif mencapai $100 \%$. Artinya tingkat ketercapaian untuk standar peralatan pendukung uji kompetensi di workshop otomotif dinyatakan sangat layak dengan mendapat skor 3 yang disesuaikan terhadap instrumen verifikasi SMK Penyelenggara Ujian Praktik Kejuruan dari BSNP. Pencapaian standar persyaratan tempat/ruang uji kompetensi di workshop otomotif mencapai $98,2 \%$. Artinya tingkat ketercapaian untuk standar persyaratan tempat/ruang uji 
kompetensi di workshop otomotif dinyatakan sangat layak dengan mendapat skor 2,85 yang disesuaikan terhadap instrumen verifikasi SMK Penyelenggara Ujian Praktik Kejuruan dari BSNP. Pencapaian standar persyaratan penguji internal uji kompetensi di workshop otomotif mencapai 100\%. Artinya tingkat ketercapaian untuk standar persyaratan penguji internal uji kompetensi di workshop otomotif dinyatakan sangat layak dengan mendapat skor 3 yang disesuaikan terhadap instrumen verifikasi SMK Penyelenggara Ujian Praktik Kejuruan dari BSNP. Sarana dan prasarana yang terdapat di workshop Teknik Mekanik Otomotif SMK Negeri 8 Bandung bisa memenuhi standar uji kompetensi dengan ketercapaian 98,6\%. Artinya sangat layak untuk dijadikan tempat pelaksanaan ujian kompetensi.

\section{KESIMPULAN}

Kesimpulan dari penelitian ini, yaitu sarana workshop Teknik Otomotif SMK Negeri 8 Bandung yang ada sekarang sudah memenuhi Standar Nasional Pendidikan dengan ketercapaian 85,7\% yang artinya sangat layak/sangat lengkap. Prasarana di workshop yang ada sekarang sudah memenuhi Standar Nasional Pendidikan dengan ketercapaian $75 \%$ yang artinya layak/ lengkap. Sarana dan prasarana yang terdapat di workshop yang ada sekarang bisa memenuhi standar uji kompetensi dengan ketercapaian 98,6\% yang artinya sangat lengkap/sangat layak.

\section{DAFTAR PUSTAKA}

Arbor, A. (1992). Modern School Shop Planning. Michigan USA: Prakken Publications Inc.

Barnawi \& Arifin, M. (2012). Manajemen Sarana dan Prasarana Sekolah. Jogjakarta: ArRuzz Media.

Kemendiknas. (2008). Peraturan Menteri Pendidikan Nasional Nomor 40 Tahun 2008. [Online]. http://akhmadsudrajat.files.wordpress.com/2009/04/ permen-no-40-tahun2008-standar-sarana-prasaranastandar-smk.pdf/.

Permana, T. (2012) Bab I Bengkel Otomotif. [Online]. Diakses: http://file.upi.edu/browse. php?dir=Direktori/fptk/jur._pend._teknik_mesin/196511101992031tatang_permanal 